REVISTA DE DERECHO UNED, NÚM. 23, 2018

\title{
ORIGEN DE LOS SEGUROS DE INVALIDEZ, VEJEZ Y MUERTE A TRAVÉS DE LA NORMATIVA Y LOS CONGRESOS DE ORGANIZACIÓN INTERNACIONAL DEL TRABAJO Y SU RECEPCIÓN EN ESPAÑA
}

\author{
ORIGIN OF THE DISABILITY, OLD-AGE AND DEATH \\ INSURANCE THROUGH THE LABOUR REGULATIONS \\ AND THE CONGRESSES OF THE INTERNATIONAL LABOUR \\ ORGANIZATION AND ITS RECEPTION IN SPAIN
}

RAFAEL DÍAZ MOYA

Doctorando en Derecho y Ciencias Sociales. UNED. Madrid, 2018

Resumen: El estudio consiste en determinar si existen evidencias que nos permitan determinar la existencia del origen real del concepto de invalidez como derecho social exigible que permita diferenciarlo de la atención que se dispensaba al inválido, de carácter proteccionista, o si, por el contrario, existió una evolución de un proceso de sistematización de la asistencia.

Podría pensarse que, la influencia de la beneficencia en la Constitución de 1812, su reforma en 1849 y la existencia de corrientes como Spencer y Nietzsche que deseaban que cada cual debía sufrir las consecuencias de su conducta en aras de un espíritu liberal, España se encaminaba a una intervención del Estado bajo el prisma de la religión.

No obstante, el espíritu reformista de intervencionismo científico en las relaciones de producción de sectores progresistas de la burguesía en defensa del orden económico capitalista krausista marcaría, especialmente en el primer lustro de la década de los años 30 del 
siglo Xx, un punto de inflexión en la evolución histórica de la protección social de la invalidez como derecho exigible, aunque en aquel momento limitado a las relaciones de producción.

Palabras clave: Invalidez, reforma, legislación laboral, trabajo, convención.

Abstract: The study consists of determining if there exist pieces of evidence that allow us to determine the existence of the real origin of the concept of disability as a social right exigible that it protectionist, that allows to distinguish it from the attention that was given to the disabled person or if, on the contrary, there existed an evolution of a process of systematization of the assistance.

There might be thought that, the influence of the welfare in the Constitution of 1812, his reform in 1849 and the existence of currents as Spencer and Nietzsche who were wishing that everyone had to suffer the consequences of the conducts of them on altars of an liberal spirit, Spain was directing to an intervention on the prism of the religion.

Nevertheless, the spirit reformist of scientific interventionism in the relations of production of liberal and progressive sectors of the middle class in defense of the economic capitalist order Krausist would mark, in the second decade of the 20th century, a point of inflexion in the historical evolution of the social protection of the disability as right exigible, even if in that moment it was limited to the relations of production.

Keywords: Disability, reform, labour legislation, work, convention.

Recepción original: 22/03/2018

Aceptación original: 11/12/2018

Sumario: I. Origen del concepto de invalidez y su evolución constitucional.-II. El concepto de dignidad en la constitución gaditana como antecedente de la garantía de derechos.-III. El origen del intervencionismo del Estado en las relaciones de producción. A. La Conferencia Internacional del Trabajo de 1932. B. El proyecto de Inocencio Jiménez en la unificación de los seguros sociales en la XVII Conferencia Internacional del Trabajo de 1933.-IV. El concepto jurídico de invalidez en relación con el concepto de dignidad humana.-V. Conclusiones. 


\section{ORIGEN DEL CONCEPTO DE INVALIDEZ Y SU EVOLUCIÓN CONSTITUCIONAL}

El punto de partida para resaltar la necesidad de reconocer unos derechos que comenzaban a ser esenciales para la vida se considera en el Pacto Internacional de Derechos Sociales, Económicos y Culturales que reconoce que «con arreglo a la Declaración Universal de Derechos Humanos, no puede realizarse el ideal del ser humano libre a menos que se creen las condiciones que permitan a cada persona gozar de sus derechos económicos, sociales y culturales, tanto como sus derechos civiles y políticos» ${ }^{1}$. El primer ingreso de estos derechos en un orden jurídico positivo tuvo lugar en Alemania, después de la primera guerra mundial con la Constitución de Weimar en 1919, aunque «no dejaban de ser una declaración de intenciones para dar cabida a los derechos civiles, políticos, y sociales»².

La primera referencia constatable relativa a una posible definición - aunque no registrada como tal- del término inválido se acuña por Torres Villarroel en el año 1725 relativa al quartel de inválidos se definía como "gente con tantos desgarrones en la vida como en vestido, desechados del mundo, aborrecidos de la guerra, y hacinados en aquel Calvario de vivientes, para que se acabasen de podrir sus magulladas y hediondas carnes ${ }^{3}$.

La primera referencia del término inválido en el Diccionario Académico de 1726 hace constancia al término cédula de inválido como «la Orden que concedía el Rey a algún soldado que pasase a la Compañía de Inválidos» ${ }^{4}$, así como si "algún Piloto... que hubiere obtenido cédula de inválido» ${ }^{5}$.

1 MARRADES, A., "Los nuevos derechos sociales: El derecho al cuidado como fundamento del pacto constitucional», en Revista de Derecho Político, núm. 97, septiembre-diciembre 2016, pág. 211.

2 Ibidem., pág. 214.

${ }^{3}$ Real Academia Española, Nuevo Diccionario Histórico del Español, Instituto de investigación Rafael Lapesa, Madrid, en la referencia inválido, pág. 4, entrada 74. TORRES VILLARROEL, D., Extracto de los Pronósticos del gran Piscator de Salamanca, desde el año de 1725 hasta el de 1744, CORDE, Madrid, RAE, 2006, Astrología y ciencias ocultas [recuperado el 13/03/2018, en http://web.frl.es/CNDHE/ org/publico/pages/consulta/entradaCompleja.view].

${ }_{4}$ Diccionario Histórico del Español (1933-1936). En la referencia cédula de inválidos, pág. 932. Cfr. Dicc. Acad., 1726, s.v. [recuperado el 13/03/2018 en http:// web.frl.es/DH1936.html].

5 Ídem. En la referencia cédula de inválidos. Cfr. Cédula de la Armada, 1793, t. 2, pág. 406 [recuperado el 13/03/2018, en http://web.frl.es/DH1936_ART \%C3\%8DCULOS/A_Cevilla_PDF/Tomo_II_0932.pdf\#xml=http://web.frl.es/dtSearch/ dtisapi6.dll cmd $=$ getpdfhits $\& u=8 \mathrm{cce} 47 \&$ DocId $=932 \&$ Index $=\mathrm{C} \% 3 \mathrm{a} \% 5 \mathrm{cinet}$ pub $\% 5 \mathrm{cwwwroot} \% 5 \mathrm{cDH} 1936 \% 5 \mathrm{fPDF} \&$ HitCount $=1 \& \mathrm{hits}=159+\&$ Search Form $=\mathrm{C} \% 3 \mathrm{a} \% 5$ cinetpub $\% 5$ cwwwroot $\% 5 \mathrm{cDH} 1936 \% 5$ fform $\% 2 \mathrm{ehtml} \&$.pdf].

(C) UNED. Revista de Derecho UNED, núm. 23, 2018 
La primera entrada que registra el concepto de inválido en el diccionario razonado de legislación y jurisprudencia de Escriche en sus diferentes versiones referido a las personas-referencias anteriores como la de $1831^{6}$ y $1838^{7}$ determina «...a lo que es nulo» referido a las cosas-, data de la edición de $1839^{8}$ en la que su acepción se refiere "al soldado que por haber quedado estropeado... los oficiales, sargentos y cabos y soldados...». Esta acepción-conjuntamente con la versión del diccionario de $1847^{9}$, no de su suplemento ${ }^{10}$ ni la de $1854^{11}$-refleja una relación exclusiva entre el concepto de inválido y el ámbito castrense, no incluyéndose ninguna acepción fuera de este ámbito, extendiéndose dicha relación desde la versión de $1854^{12}$ hasta la de $1875^{13}$.

La Real Academia Española de la Lengua en su última versión, en su segunda acepción establece que el inválido será el que «ado-

${ }^{6}$ ESCRICHE, J., Diccionario razonado de legislación civil, penal, comercial y forense, Imprenta de P. Dupont et G.-Laguionie, Paris, 1831, pág. 322. «Lo que es nulo y de ningún valor por no tener las condiciones que exigen las leyes. Invalidar es hacer o declarar nula y de ningún efecto alguna cosa.»

7 ESCRICHE, J., Diccionario razonado de legislación civil, penal, comercial y forense, Imprenta de J. Ferrer de Orga, Valencia, 1838, pág. 316. «Lo que es nulo y de ningún valor por no tener las condiciones que exigen las leyes. Invalidar es hacer ó declarar nula y de ningún efecto alguna cosa.»

${ }^{8}$ ESCRICHE, J., Diccionario Razonado De Legislación Y Jurisprudencia. 2. a ed. corr. y aum. Madrid: Imprenta del Colegio de Sordo-mudos, pág. 536 [recuperado el 13/03/2018, en https://babel.hathitrust.org/cgi/pt?id=ucm.5319399529;view= 1up;seq=544].

9 ESCRICHE, J., Diccionario razonado de legislación y jurisprudencia, Tomo segundo, Madrid, 1847, pág, 235, Véase Colón tomo 2, ns 1316 y 1317, [recuperado el 13/03/2018, en https://babel.hathitrust.org/cgi/pt?id=ucm.5319425852; view= 1up;seq=239].

10 ESCRICHE, J., Suplemento al diccionario razonado de legislación y jurisprudencia, Madrid, Establecimiento tipográfico-literario Universal la ilustración, 1847 [recuperado el 13/03/2018, en https://babel.hathitrust.org/cgi/pt?id= ucm.5319400449; view=1up;seq=5

11 ESCRICHE.J., Suplemento al diccionario razonado de legislación y jurisprudencia, Librerías de D. Ángel Calleja, Madrid y Santiago, 1851, [recuperado el 13/03/2018, en https://babel.hathitrust.org/cgi/pt?id=ucm.5319404502; view= 1up;seq=9].

${ }_{12}$ ESCRICHE, J., Diccionario razonado de legislación y jurisprudencia, Libería de Rosa, Bouret y Cía, París, 1854, pág. 933. «El soldado que por haber quedado estropeado... los oficiales, sargentos y cabos y soldados...» Véase Colón tomo 2, ns. 1316 y 1317.

${ }^{13}$ ESCRICHE, J., Diccionario razonado de legislación y jurisprudencia, Imprenta de Eduardo Cuesta, Madrid, 1875, pág. 415. Véase Colón tomo 2, núm. 1316 y 1317 Jurisdicción militar y jurisdicción militar ordinaria. [recuperado el 13/03/2018, en https://babel.hathitrust.org/cgi/pt?id=mdp.39015080320735;view=1up;seq=7]. 
lece de un defecto físico o mental, ya sea congénito, ya adquirido, que le impide o dificulta alguna de sus actividades» ${ }^{14}$.

Según el Diccionario de Español Jurídico, el concepto de inválido remite al concepto de invalidez por el que su acepción expresa «una discapacidad valorada por el servicio competente a efectos de determinar el grado de compatibilidad con el trabajo y el derecho al reconocimiento de determinadas prestaciones o pensiones, distinguiéndose entre invalidez parcial, invalidez total, invalidez absoluta y gran invalidez ${ }^{15}$.

Según el Diccionario de Autoridades, la acepción de inválido se definía en el año 1734, no como característica de la persona sino en relación con las cosas ${ }^{16}$.

En el Diccionario Histórico de la Lengua Española (1960-1996), el término invalidez se encuentra registrado bajo el epígrafe del accidente de trabajo en la referencia del Fuero del Trabajo X de $1954{ }^{17}$.

No será hasta el Convenio de 8 de junio de 1933, relativo al Seguro obligatorio de invalidez, aprobado en la XVII Conferencia Internacional del Trabajo, artículos 9 y 23 cuando el concepto de invalidez tome forma jurídica por la que quedó definido, a los efectos de la Ley, a «todo el que, por causa no imputable a él ni derivada de un accidente de trabajo o enfermedad profesional indemnizable, no pueda ganar, en un trabajo adecuado a sus fuerzas, sus capacidades, su instrucción y la profesión ejercida anteriormente, un tercio, al menos, de lo que gane habitualmente un asalariado de la misma

${ }^{14}$ Diccionario de la Real Academia de la Lengua. Actualización 2017, Madrid, España. En la referencia invalidez (2) [recuperado el 13/03/2018, en http://dle.rae. es/?id=M24bTeo

${ }^{15}$ Diccionario de Español-jurídico, Madrid, España. En la referencia invalidez [recuperado el 13/08/2018, en http://dej.rae.es/\#/entry-id/E145710].

16 Diccionario de Autoridades (1726-1739), Tomo IV (1734) [recuperado el 13/03/2018, en http://web.frl.es/DA.html]. Cosa írrita, sin valor o fuerza. Es del Latino Invalidus, a, um. MARIAN. Hist. Esp. lib. 23. cap. 19. Por ser casamientos que se hacen entre deudos, no solo inválidos, sino desgraciados. SOLORZ. Polit. lib. 3. cap. 31. Aunque esa buena fe se haya causado de títulos inválidos, injustos o temerarios.

17 Diccionario Histórico de la Lengua Española (1960-1996). En la referencia accidente de trabajo: «Lesión corporal que sufre el operario con ocasión o a consecuencia del trabajo que ejecuta por cuenta ajena.» Crf. 1920 Dicc. Ciencias Méd. Cardenal. 1925-1956 Ac. 1938 Fuero del Trabajo X 2 (1954) 195. Se incrementarán los seguros sociales de: vejez, invalidez, maternidad, accidentes del trabajo, enfermedades profesionales [recuperado el 13/03/2018, en http://web.frl.es/DH.html]. 
categoría, sano física y mentalmente, de instrucción análoga, en la misma localidad» ${ }^{18}$.

Desde un análisis histórico constitucional, no existe ningún articulado que recoja el concepto de invalidez hasta la Constitución republicana de 1931. La primera vez que se realiza una aproximación a lo que pudiera relacionarse con el término inválido, etc., hace referencia a la condición de incapacidad —no el derecho-en el Título 2. ${ }^{\circ}$ Del territorio de las Españas, su religión y Gobierno, y de los Ciudadanos Españoles, Capítulo 4. ${ }^{\circ}$ De los Ciudadanos Españoles de la Constitución de 1812, donde fuera de cualquier reconocimiento, el artículo 25 excluye del ejercicio de ciudadanía «la incapacidad física por interdicción judicial» ${ }^{19}$.

En la Constitución de 1834, en su artículo 10, relativo al Título II Del Estamento del Próceres del Reino, en relación a la articulación de los cargos políticos y la dignidad nobiliaria, determina que «la dignidad de Prócer del Reino se pierde únicamente por incapacidad legal...» ${ }^{20}$. En el Título III Del estamento de Procuradores del Reino, artículo 15 excluye del acceso a la procuraduría del Reino a los que «tengan alguna discapacidad física, notoria o de naturaleza perpetua $»^{21}$.

Desde la Constitución de 1837 hasta la republicana de 1931, las menciones relativas al concepto de incapacidad quedan recogidas exclusivamente al ámbito de la Corona ${ }^{22}$.

18 INSTITUTO NACIONAL DE PREVISIÓN, El nuevo Seguro de invalidez en el Proyecto de unificación de seguros sociales, Hoja divulgadora del Instituto Nacional

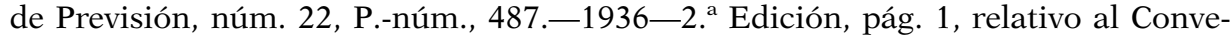
nio de 8 de junio de 1933, relativo al Seguro obligatorio de invalidez, aprobado en la XVII Conferencia Internacional del Trabajo, artículos 9 y 23.

19 DÍAZ RICO, J.C., "Constituciones españolas 1808-1978» en DDPPHD-HD-Monografías. Serie Historia del Derecho, núm. 42, Madrid, 2016, pág. 34 [recuperado el 12/08/2017, en http://hdl.handle.net/10016/22905].

${ }^{20}$ Ibídem, pág. 83.

${ }^{21}$ Ibídem, pág. 84.

${ }^{22}$ Ibídem., pág. 94. En la Constitución de 1837, en su artículo 54, relativo al Título 7. ${ }^{\circ}$ De la sucesión a la Corona, determina que «Las Cortes deberán excluir de la sucesión aquellas personas que sean incapaces para gobernar...», pág. 105. En la Constitución de 1845, en su artículo 154, relativo al Título séptimo De la sucesión a la Corona, articula que «Las personas que sean incapaces para gobernar, o hayan hecho cosa por que merezcan perder el derecho a la Corona, serán excluidas de la sucesión por una ley.», pág. 116. La Constitución de 1856, en su artículo 58, relativo al Título VII De la Sucesión a la Corona, articula «Las Cortes excluirán de la sucesión aquellas personas que sean incapaces para gobernar...», Pág. 134. La Constitución de 1869, en su artículo 80, relativo al Título QUINTO De la Sucesión a la Corona y de la Regencia del Reino articula en los mismos términos anteriores «Las Cortes excluirán de la sucesión a aquellas personas que sean incapaces para gober- 
En la Constitución republicana de 1931 en el Título III Derechos y deberes de los españoles, Capítulo II Familia, economía y cultura, artículo 46, expresa la protección de la invalidez en el trabajo como obligación social: «La República asegurará a todo trabajador las condiciones necesarias de una existencia digna. Su legislación social regulará: los casos de seguro de enfermedad, accidente, paro forzoso, vejez, invalidez y muerte; el trabajo de las mujeres y de los jóvenes, y especialmente la protección a la maternidad; la jornada de trabajo y el salario mínimo y familiar; las vacaciones anuales remuneradas; las condiciones del obrero español en el extranjero; las instituciones de cooperación; la relación económico jurídica de los factores que integran la producción; la participación de los obreros en la dirección, la administración y los beneficios de las empresas, y todo cuanto afecte a la defensa de los trabajadores» ${ }^{23}$.

Relacionando el PIDESC con la Constitución Española de 1978, (CE-1978), observamos que los derechos sociales en relación a nuestro análisis es, aparte del derecho al trabajo, vivienda, protección de la salud, educación y cultura, el derecho a la seguridad social. La protección de las personas con discapacidad queda recogido en el artículo 49 de la CE-1978 pero no configura «en absoluto» un derecho subjetivo, sino como "políticas que se proyectan en una pluralidad de ámbitos bien diferenciados (laborales, culturales, vivienda, educación, ocio, deportes, etc.)» ${ }^{24}$. La protección de las personas con invalide ${ }^{25}$, aunque no recogido directamente en la CE-1978 fuera del artículo 50 sin salir del ámbito de la tercera edad, pertenece a esa esfera un tanto ambigua de los derechos sociales cuya efectivi-

nar», pág. 168. La Constitución de 1876, en su artículo 64, relativo al Título séptimo, De la Sucesión a la Corona articula en los mismos términos anteriores «Las personas que sean incapaces para gobernar, o hayan hecho cosa porque merezcan perder el derecho a la Corona, serán excluidas de la sucesión por una ley.»

${ }^{23}$ Ibídem., pág. 183.

${ }^{24}$ GARCÍA MARTÍNEZ, A., Sinopsis del artículo 49 de la Constitución Española de 1978, Congreso de los Diputados, 2003, pág. 1 [recuperado el día 12/02/2018, en http://www.congreso.es/consti/constitucion/indice/sinopsis/sinopsis.jsp?art= 49\&tipo=2 ]

25 GARCÍA MARTÍNEZ, A., Sinopsis del artículo 50 de la Constitución española de 1978, Congreso de los Diputados, 2003, pág. 1 [recuperado el día 12/02/2018, en http://www.congreso.es/consti/constitucion/indice/sinopsis/sinopsis.jsp?art= $50 \&$ tipo=2 ] donde especifica que son varios los textos internacionales que atienden a la problemática de la protección social de la tercera edad; entre ello son significativos la Carta Social Europea de 18 de octubre de 1961, el Código Europeo de Seguridad Social (Estrasburgo, 16 de abril de 1964, ratificado por España el 4 de febrero de 1994), así como el Convenio n. ${ }^{\circ}$ 128, de 29 de junio de 1967, de la Organización Internacional del Trabajo relativo a las prestaciones de invalidez, vejez y sobrevivientes. 
dad depende más de la acción efectiva del Estado que del enunciado constitucional directo (art. 53.3 CE) ${ }^{26}$ como todos los artículos del Capítulo III, del Título I de la Constitución con la denominación de Principios al no ser reconocidos como derechos fundamentales, como veremos posteriormente.

\section{EL CONCEPTO DE DIGNIDAD EN LA CONSTITUCIÓN GADITANA COMO ANTECEDENTE DE LA GARANTÍA DE DERECHOS}

El concepto moderno de Constitución, se puede situar en el artículo 16 de la Declaración de Derechos del Hombre y del Ciudadano, de la Asamblea Nacional francesa en 1789, y que indicaba: «Toda sociedad en la que no esté asegurada la garantía de los derechos ni determinada la separación de poderes no tiene Constitución». Desde entonces, y tomando como fundamento los postulados contractualistas de la Ilustración que entendían la Constitución como un "pacto social» básico ${ }^{27}$, se ha convenido que existe Constitución en una sociedad si los derechos están garantizados conjuntamente con la separación de poderes considerando, según Otto, que la organización de poderes públicos de una sociedad debe responder al aseguramiento y garantía de la libertad de los ciudadanos, principalmente frente a dichos poderes públicos ${ }^{28}$, aunque en la Constitución de Cádiz no ocurra.

La Constitución Política de la Monarquía Española, promulgada en Cádiz el 19 de marzo de 1812, de corte liberal, es el más univer-

26 Ídem., La promulgación de la Ley 51/2003, de 2 de diciembre, de Igualdad de oportunidades, no discriminación y accesibilidad universal de las personas con discapacidad, cuya exposición se aborda en el comentario al art. 49 de la Constitución, proyecta su ámbito tuitivo también sobre el colectivo de personas mayores en cuanto éstas puedan conceptuarse como discapacitadas según la definición contenida en el art. 1.2 de dicha ley: tienen la consideración de personas con discapacidad aquellas a quienes se les haya reconocido un grado de minusvalía igual o superior al 33 por 100 . En todo caso, se consideran afectados por una minusvalía en grado igual o superior al 33 por 100 los pensionistas de la Seguridad Social que tengan reconocida una pensión de incapacidad permanente en el grado de total, absoluta o gran invalidez, y a los pensionistas de clases pasivas que tengan reconocida una pensión de jubilación o de retiro por incapacidad permanente para el servicio o inutilidad. Para una exposición algo más amplia del contenido de esta ley, véase el comentario al art. 49 de la Constitución.

27 CAMISÓN J.A., «La Constitución de 1812 y su proyección a nuestros días» en PALACIOS, L. y RUIZ, I. (directores), Cádiz 1812, origen del Constitucionalismo español, Ed. Dykinson, Madrid, 2013, págs. 429-444.

${ }^{28}$ Ídem, Cfr. en OTTO, I., Derecho Constitucional. Sistema de Fuentes, Barcelona, Ed. Ariel, 1988, pág. 12. 
sal de los textos constitucionales españoles que desencadenó una serie de dinámicas que permitieron sentar las bases del inicio de una cultura constitucional ${ }^{29}$. En Cádiz influyen dos modelos de constitución, la inglesa y francesa o, como indica Garriga, «dos concepciones que encarnan en sendos modelos de constitución, la constitución-orden (tradicional) y la constitución-norma (moderna) $»^{30}$, los cuales, suscitan, hoy en día, una confrontación dialéctica respecto al cambio que se produjo. Según el autor, este «concepto moderno de Constitución» ${ }^{31}$ liberal se caracterizaba, fundamentalmente, por el aseguramiento y garantía una serie de derechos del ciudadano frente al Estado - fundamentalmente el derecho a la propiedad privadaSin embargo para Suárez Cortina, el eje de la evolución constitucional del concepto de ciudadano pivotaba sobre la base de una «ciudadanía católica»32 debido, como expresa Alonso García, a «la articulación política de corte confesional ${ }^{33}$ del texto gaditano. Tal vez, como expresa Tomás y Valiente, recogido por Tajadura, España prefirió reafirmar el texto gaditano bajo su tradición histórica como respuesta a su autodeterminación y reafirmación en su lucha contra Francia en un proceso de «mitificación de la historia constitucional de España ${ }^{34}$ como una "vacuna frente a posibles acusaciones dirigidas por los partidarios del Antiguo Régimen a los liberales tachándolos de revolucionarios ${ }^{35}$.

Por lo tanto cabe preguntarse hasta qué punto la Constitución gaditana es un nuevo orden o es la continuación de lo preexistente en relación a un cambio cualitativo en el reconocimiento de derechos. Valga el ejemplo su artículo 12: «La religión de la Nación española es y será perpetuamente la católica, apostólica, romana, única

${ }^{29}$ LORENTE, M., VALLEJO, J. (coords.) et al., Manual de Historia del Derecho, Tirant lo Blanch, 2012, págs. 342-343.

${ }^{30}$ GARRIGA ACOSTA, C.A., "Cabeza moderna, cuerpo gótico. La Constitución de Cádiz, y el orden jurídico», en AHDE LXXXI, 2011, págs. 99-162, pág. 126 para la cita [recuperado el 10/01/2018, en https://app-vlex-com.ezproxy.uned.es/?r=true\#].

31 Ibídem., pág. 133.

32 SUAREZ CORTINA, M., Entre cirios y garrotes: política y religión en la España contemporánea. (1808-1936), Universidades de Castilla-La Mancha y de Cantabria, 2014, pág. 36. Cfr. CAÑAS DE PABLOS, A., «Liberalismo sin libertad: unidad religiosa y orden público de las Constituciones españolas de 1812 y 1837 » en Revista de Historia Constitucional, núm. 17, 2016, págs. 83-102, pág. 84 para la cita.

33 ALONSO GARCÍA, G., "Ciudadanía católica y ciudadanía laica en la experiencia liberal», en Manuel Pérez Ledesma (dir.), De súbditos a ciudadanos. Una historia de la ciudadanía en España, Madrid, CEPC, 2007, pág. 172.

${ }^{34}$ TAJADURA TEJADA, J., «El discurso preliminar de Agustín Argüelles a la Constitución de Cádiz», en Rev. Pensamiento Constitucional, Año VIII, núm. 8, págs. 415-430, pág. 418 para la cita.

35 Ibídem., pág. 428. 
verdadera. La Nación la protege por leyes sabias y justas y prohíbe el ejercicio de cualquiera otra ${ }^{36}$.

En un proceso reformista, no cabría que la religión fuera de tal influencia, que el catolicismo fuese condición sine qua non para adquirir la condición de ciudadanía. Respecto de este asunto, la libertad de culto, relativa al «contrato social» no se aceptará hasta la Constitución de 1869. Por lo que, según Grimm, el «concepto rupturista» de la Constitución de 1812, que proclamaría un instrumento contractual alejado de las obligaciones de los individuos que vinculan al que detenta el poder- origen divino- con sus súbditos ${ }^{37}$, no existiría porque el precepto moderno de Constitución por el que "prescribe su origen en la voluntad del pueblo» ${ }^{38}$ no se habría formulado. Más bien, como expresa Horst Dippel, fuera de toda discusión, la Constitución de 1812 habría constituido «el más importante intento en Europa, en la primera mitad del siglo XIX de combinar la esencia del constitucionalismo moderno con el orden monárquico existente ${ }^{39}$.

No obstante lo dicho, un rasgo a tener en cuenta de la Constitución de Cádiz fue que ya contuviera un mandato expreso a los poderes públicos para que velaran por la progresiva reducción de la deuda pública; mandato éste idéntico a la nueva regulación de limitación del gasto público establecida a través de la modificación del artículo 135 de la Constitución española de $1978^{40}$. En la Constitución de 1812, la liquidación de la deuda pública debía ser una de las «primeras atenciones de las Cortes» ${ }^{41}$, hecho éste que encaja con la

${ }^{36}$ DÍAZ RICO, J.C., op. cit., pág. 33 [recuperado el 12/02/2018, en http://hdl. handle.net/10016/22905].

37 GRIMM, D., Constitucionalismo y Derechos Fundamentales, Editorial Trotta, Madrid, 2006, pág. 48.

38 Ibídem., pág. 111.

39 SÁNCHEZ ARANDA, A., "A propósito de la idea de justicia en el constitucionalismo gaditano: el largo camino hacia la independencia judicial» en PALACIOS, L., RUIZ RODRÍGUEZ, I., Cádiz 1812. Origen del constitucionalismo español, págs. 365-385, pág. 354 para la cita.

40 Citado en Reforma del art. 135 de la Constitución, de 27 de septiembre de 2011, publicada en el BOE n. ${ }^{\circ} 233$ de 27 de septiembre de 2011. La obligación constitucional autoimpuesta se sustancia sobre la aplicación del Pacto de Estabilidad y Crecimiento. En este sentido, el fundamento jurídico del pacto se encuentra en los artículos 121 y 126 del Tratado de Funcionamiento de la Unión Europea basado principalmente en dos pilares: el principio de supervisión multilateral de las situaciones presupuestarias y el procedimiento de déficit excesivo. Véase Unión Europea, Tratado de Funcionamiento de la Unión Europea, de 30/03/2010, Diario Oficial de la Unión Europea C 83/97-98 art. 121 y art. 126 [recuperado el día 04/03/2018, en https://www.boe.es/doue/2010/083/Z00047-00199.pdf].

${ }^{41}$ DÍAZ RICO, J.C., op. cit., pág. 77. Artículo 355 de la Constitución de 1812. 
lógica liberal económica y la limitación de la intervención del Estado, como alega Lasarte, bajo la idea superpuesta del concepto de Nación económica sobre los derechos individuales ${ }^{42}$ vinculado a la raigambre francesa del poder constituyente de un Estado que quedó recogido en el artículo 3 del texto gaditano y que enlaza directamente con el concepto de nación del artículo 2 del texto constitucional vigente ${ }^{43}$. Esto se explica porque el concepto de propiedad y de libertad en el liberalismo económico de la época se sustentaba sobre la consideración de no diferenciar derechos fundamentales y patrimoniales: «la finalidad principal radicaba en la libertad individual mientras que la propiedad venía a constituir un colofón de aquella... en consecuencia....por obra y gracia de la Revolución Francesa, los dos polos del binomio libertad-propiedad se elevan rápidamente a la categoría de ideales, adquiridos por cada individuo, que posibilitarán, por fin, la igualdad social» ${ }^{44}$.

Ante la falta de discusión, el predominio de una concepción liberal de las nuevas Cortes depositarias de la soberanía constituyó, sin una «representación teórica y real de los movimientos populares hacia los parlamentos representativos debido a la ocupación francesa $»^{45}$, una idea de nación sobre un concepto económico basado exclusivamente en el derecho a la propiedad sobre una base del concepto de ciudadanía como varón católico, blanco, propietario y de alto nivel de renta, superpuesto a los derechos individuales.

Unido al hecho de intentar ocultar la influencia de los modelos constitucionales precedentes explicaría, probablemente, porque la Constitución no tuvo tampoco en su articulado un título específico dedicado a Derechos y Obligaciones de los españoles como se había realizado en la Constitución francesa ${ }^{46}$. La Comisión de Constitución elegida por las Cortes Generales y Extraordinarias, que comenzó sus sesiones el 2 de marzo de 1811, decidió que los derechos eran los de

${ }^{42}$ LASARTE, C., «Génesis y constitucionalización de la función social de la propiedad», en A. López, A. y C. Lasarte, C., Programa y materiales de Derecho civil III, Sevilla 1978, pág. 103.

43 MOREU BALLONGA, J.L., «La expansiva reforma legal (1999-2001) del derecho civil aragonés y la reforma estaturaria aragonesa de 2007» en Ivs Fvgit, núm. 16, 2009-2010, págs. 119-143, pág. 130 para la cita. Cfr. en tal sentido, LASARTE, C., Autonomías y Derecho privado en la Constitución española, Cuadernos Civitas, Madrid, 1980, pág. 27.

${ }^{44}$ LASARTE, C., Propiedad y derechos reales de goce. Principios de Derecho Civil

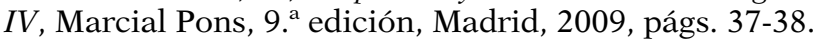

${ }^{45}$ LASARTE, J., Las Cortes de Cádiz: soberanía, separación de poderes, Hacienda, 1810-1811, Marcial Pons, 2009, pág. 18.

46 Se pueden consultar las actas de la Comisión de Constitución, en http://www. cervantesvirtual.com/obra/actas-de-la-comision-de-constitucion-1811-1813/ 
la propiedad, libertad, la seguridad e igualdad ${ }^{47}$, estos tres últimos como accesorios. Ante la falta de un título específico de derechos fundamentales en la Constitución gaditana se establecen a lo largo de su articulado, «de manera dispersa, una serie de derechos» ${ }^{48}$, a modo de libertad de defensa ${ }^{49}$ "tanto la libertad política (constitutivamente desigual), como la libertad natural (formalmente igual) ${ }^{50}$. También las limitaciones a las competencias reconocidas al Supremo Tribunal, se evidenciaba que no seguirían plenamente el modelo francés de la Corte de Casación no pudiendo considerarse, «un Tribunal de casación puro ${ }^{51}$ desechando la idea de una jurisprudencia como base para interpretar la Constitución en base a la unidad de doctrina ${ }^{52}$ ni siquiera desde el límite a la propiedad privada ${ }^{53}$ : «Los derechos declarados por la Constitución de 1812 correspondieron a un sujeto imaginado, a la par colectivo y católico, y no a los reales de carne y hueso cuyos derechos dependían del reconocimiento y regulación que de ellos hiciera un poder legislativo comprometido con la defensa de la catolicidad $»^{54}$.

Otro rasgo del texto gaditano cuya influencia se derivó hasta la Constitución de 1978 en lo concerniente a la mujer, fue la consagración de una presupuesta «igualdad» de todos los ciudadanos y su derecho a participar en la organización de la vida social ${ }^{55}$, mediante el

${ }_{47}$ El capítulo fue presentado por los mencionados diputados en la sesión de 10 de abril de 1811, en el siguiente articulado: Capítulo II DE LOS ESPAÑOLES, SUS DERECHOS Y OBLIGACIONES.

${ }^{48}$ CAMISÓN, J.A., op. cit., pág. 441, citado en PÉREZ LUÑO, E., «Razón Jurídica y libertades en la Constitución de Cádiz de 1812», en PEÑA, L. y AUSÍN, T. (coords.), Memoria de 1808. Las bases axiológico-jurídicas del constitucionalismo español, Madrid, Ed. Plaza y Valdés, 2009, págs. 173.

49 A estos se les suma los de libertad civil (art. 4), libertad personal (art. 172.11), propiedad (arts. 4, 172.10, 294 y 304), libertad de imprenta (arts. 131.24 y 371), e igualdad (no concesión de privilegios por el rey, art. 172.9, o el de igualdad contributiva, art. 339.

50 TOMÁS Y VALIENTE, F., «Los Derechos fundamentales en la Historia del Constitucionalismo español», en Obras Completas, t. III, Madrid, 1997, p. 2.024.

${ }^{51}$ FAIRÉN GUILLÉN, V., "La recepción en España del recurso de casación francés (1812-1813)», en Temas del Ordenamiento Procesal, t. I, Historia. Teoría General, Madrid, 1969, pág. 214.

52 SANCHEZ ARANDA, A., op. cit., pág. 361.

53 GARCÍA MARTÍN, J., «La exclusión histórico-constitucional de la pobreza (siglos XIX-XX): dignidad, derechos sociales y/o «derechos de la personalidad» en MORÁN MARTÍN, R., Participación y exclusión política, causas, mecanismos y consecuencias, Tirant lo Blanch, 2018, pág. 167.

${ }^{54}$ LORENTE, M. y PORTILLO, J.M., "Orígenes del Constitucionalismo en el Mundo Hispano» en Manual de historia del derecho, 2012, págs.345-346.

55 PEREDA, C., DE PRADA, M.A. y ACTIS, W., «La participación ciudadana. Algunos apuntes a partir del Barómetro Social de España» en Cuadernos de Trabajo Social, Vol. 25-2, 2012, págs. 309-319, pág. 310 para la cita. 
mandato de la participación individual, introduciendo una distinción entre españoles y ciudadanos - excluyendo a las mujeres- y, en el caso de éstos, entre ciudadanos activos y pasivos, excluyendo del sufragio activo, no ya del concepto de ciudadanía, sino de la condición de español. Aparte de las mujeres y los menores, se suspendía el concepto de ciudadanía a los incapaces por la condición de vago - no tener empleo-, es decir, a los que no tuvieran autonomía económica - castigando la condición personal de los inválidosa, como mínimo desde la Constitución de 1869, una circunstancia agravante de un delito. En este sentido, pasa desapercibido el artículo 25 de la Constitución de 1812 en alusión clara a la suspensión individual de derechos "por el estado de sirviente doméstico» en el que en el proyecto de Código Civil de 1821, en el título III del libro primero, se incluye «De la pérdida, suspensión o preservación de derechos» que, en relación al artículo 25 de la Constitución de 1812, «se repunta sirviente doméstico al que presta servicios puramente mecánicos en favor de otras personas... $»^{56}$, esto es, el trabajador asalariado. Con frecuencia, las políticas de orden público para incorporar a los pobres al sistema productivo como los talleres de empleo se basaban en la aceptación última de la pobreza como decisión divina y su financiación quedaba supeditada a la buena conciencia de los contribuyentes ${ }^{57}$, como la atención a las enfermedades, la desvalidez o la decrepitud ${ }^{58}$. De todo ello, se denota la influencia liberalcontraria a la rama positivista- como las propuestas de Spencer y Nietzsche que sostenían que cada cual debía sufrir las consecuencias de su conducta y de la lucha por la existencia en la que la determinación de los límites del Estado ${ }^{59}$ radicaban en atender las necesidades que la gestión individual no alcanzase a remediar ${ }^{60}$, no derivándose su cumplimiento desde el derecho subjetivo sino desde una óptica muy distinta. Es la más clara influencia del pensamiento liberal del

${ }^{56}$ CLAVERO, B., "Cara oculta de la Constitución: sexo y trabajo» en Revista de Cortes Generales, núm. 10, 1987, págs. 17-18. Clavero expone que «No parece gran cosa; quienes ya también se decían cridados, y en género no dual, pues las mujeres andan ya por sexo ya excluidas, mientras se mantuvieran en tal situación de dependencia»

57 PISARELLO, G., Los derechos sociales y sus garantías. Elementos para una reconstrucción, Trotta, Madrid, 2007, pág. 21. «Sea la limosna —decía Vives- absolutamente libre cada uno con lo que le proponga su corazón, no de mala gana ni obligado».

58 ARIAS MIRANDA, J., Reseña histórica de la Beneficencia en España, Imprenta del colegio de sordomudos y de ciegos, Madrid, 1862, pág. 138.

59 ALLER, D.E., El Estado y las clases obreras, Madrid, 1894, págs. 8 y ss.

${ }^{60}$ Ibídem, pág. 10. «Tanto para que la beneficencia pública participe del carácter moralizador de la beneficencia privada, como para que ésta pueda contar con el auxilio de aquélla, es preciso combinar ambas uniéndolas en lo posible.» 
siglo XIX que no concibió los derechos como naturales y ni preexistes al Estado por lo que vinieron a condicionar a la libertad de los individuos $^{61}$ en el que su rasgo destacable consistió en la ausencia del concepto de dignidad vinculado a la igualdad. Por consiguiente, el derecho por excelencia sobre el que se construye la libertad y la igualdad será el de la propiedad, hasta bien entrado el siglo xx, y aun, por lo que se refiere a los derechos sociales, no se vería en ellos más que derechos de prestación sin posibilidad de exigirlos ante los tribunales. De hecho, ni siquiera en la Constitución de 1978, el constituyente optó por otorgar a los derechos sociales una mayor protección, provocando una desvinculación de la dignidad como principio, como veremos en su evolución ${ }^{62}$.

Consecuentemente, la falta de rotura con la tradición se produce mediante un encubrimiento ideológico liberal que no da el paso de considerar los derechos sociales como derecho individual al mismo nivel que el concepto de nación hasta la Constitución Republicana de 1931, la cual, como expresa Fernando Ayala, la innovación de tal consideración supone «la ordenación de los principios bajo la salvaguarda de las protecciones jurídicas especiales que defiende la Constitución [...] en términos de derechos social [...] y no como se venía haciendo hasta la Constitución de 1876 mediante regulaciones dictatoriales que respondían al pensamiento político social del liberalismo clásico y, por tanto, no había en ella previsión de una actividad legislativa en el sentido aludido ${ }^{63}$ en la que es la primera vez que «se viene a prestar un punto de apoyo lógico jurídico al derecho positivo preexistente» ${ }^{64}$. Estos rasgos son los que van a inspirar los fundamentos constitucionales contemporáneos. No obstante, la cultura de los juristas, fuera de acompañar el propósito de la República, consideró los derechos sociales en la Constitución republicana como un «intento de dotar de carácter supralegal» a esos derechos pero bajo el convencimiento de que no eran más que un derecho de prestación sin posibilidad de exigirlos ante la justicia y cuya satisfacción dependía en todo caso de criterios de oportunidad ${ }^{65}$.

${ }^{61}$ LORENTE, M., VALLEJO, J., (coords.), op. cit., pág. 379.

${ }^{62}$ GARCÍA MARTÍN, J., op. cit., págs. 168-201.

${ }^{63}$ Conferencia leída en el Centro Germano-Español de Madrid. 10 de marzo de 1932. Madrid: Sobrinos de Suc. De M. Minuesa de los Ríos, 1932.

${ }^{64}$ Ídem. Su estudio acerca del derecho social en la Constitución de 1931 era plasmación escrita de una intervención sobre el particular en el Centro GermanoEspañol de Madrid de marzo de 1932.

${ }_{65}$ MARTÍN, S. «Derechos sociales y procesos constituyentes» en Rev. Gaceta sindical reflexión y debate, nueva etapa, núm. 23, dic. 2014, págs. 37-70, pág. 56 para la cita. Cfr. en tal sentido, AYALA, F., El Derecho social en la Constitución de la República española, Madrid, Imp. Minuesa de los Ríos, 1932, págs. 5 y 11. 


\section{EL ORIGEN DEL INTERVENCIONISMO DEL ESTADO EN LAS RELACIONES DE PRODUCCIÓN}

Visto lo anterior, en España, el punto de observación debe fijarse en las relaciones de producción y del trabajo en régimen de servidumbre-no desde el marxismo sino desde conceptos que no discriminen-, las cuales generaban un conflicto social ante nuevos antagonistas sociales: la clase trabajadora, la clase propietaria de los medios de producción social y las relaciones dialécticas. Entre ellas utilizaban el conflicto sobre el que descansaba el modelo productivo y que supuso la incorporación de dos categorías culturales: el liberalismo, como un nuevo sistema productivo frente al mercantilismo, con los intereses de un capitalismo como sistema económico que derivó en un importante proceso histórico: la intervención del Estado en el problema social a través de una legislación protectora del trabajo asalariado que fuese compatible con el mantenimiento y desarrollo del modo de producción capitalista. Se inicia con la regulación del trabajo de menores mediante la Ley Benot de 24 de julio de $1873^{66}$ siendo ésta el inicio ideológico de la acción política republicana en su respuesta a la burguesía liberal ante el problema social, la paz social y una actitud moralizante y paternalista hacia la clase obrera. La política social del Estado se concretará en regular las condiciones de trabajo sobre la base de unas nuevas instituciones de gestión de los nuevos derechos sociales.

La contribución más sorprendente de los reformadores sociales de la Restauración fue el gran número de leyes promulgadas sobre diversos contenidos relacionados con el trabajo mediante un instrumento administrativo creado para poner en práctica la legislación obrera, es decir, el Instituto de Reformas Sociales (IRS). Este instituto, fue creado en el Instituto de la Gobernación el 23 de abril de 1903 con el encargo de "preparar la legislación del trabajo en su más amplio sentido, cuidar de su ejecución mediante servicios de inspección y estadística, y favorecer la acción social y gubernativa para mejorar el bienestar de las clases obreras ${ }^{67} \mathrm{o}$ intervencionismo cien-

${ }^{66}$ PALOMEQUE LOPEZ, M.C., "La intervención normativa del Estado en la «cuestión social» en la España del siglo XIX» en ESTEBAN DE VEGA, M., Pobreza, Beneficencia y Política Social, Ayer, núm. 25, 1997, págs. 103-126, pág. 113 para la cita. La Ley Benot se considera a la Ley de 24 de julio de 1873 sobre «regularización del trabajo en los talleres y la instrucción en las escuelas de los niños obreros de ambos sexos" [recuperado el 15/02/2018, en https:/www.ahistcon.org/PDF/ numeros/ayer25_PobrezaBeneficenciayPoliticaSocial_EstebandeVega.pdf].

${ }^{67}$ Ibídem, págs. 115. 
tífico ${ }^{68}$ del Estado en las relaciones de trabajo. El comienzo de esta regulación parte de la Comisión de Reformas Sociales (CRS) creada por un grupo institucionista-krausista liderado por Segismundo Moret $^{69}$ con el objetivo de analizar de los problemas sociales más que por su represión, con el fin de institucionalizar la reforma social. Unido - a través del IRS que consolida y acrecienta aquellos primeros pasos- a la creación del Ministerio de Trabajo de $1902^{70}$, se elaborarán estadísticas del trabajo y tareas de inspección, asesoramiento y divulgación de la legislación social ${ }^{71}$.

Finalmente, el Instituto Nacional de Previsión (INP) —creado mediante Ley de 27 de febrero de 1908-, que establecerá los seguros sociales, significó el creciente intervencionismo social del Estado constituyendo el germen del Estado social español ${ }^{72}$ que desembocará en el Estado de Bienestar ${ }^{73}$.

La primera fase del reformismo social en España, se debió a las propuestas y proyectos sociales de estas élites que irían por delante de la demanda social y de la realidad económica de España destacando la aplicación de una ley como la de accidentes de trabajo de $1900^{74}$ considerándose el mayor avance para el equilibrio entre sociedad y Estado ${ }^{75}$ conjuntamente con el Seguro de Vejez. Esta ley se centra en la configuración jurídica y en la implantación definitiva de aquel nuevo organismo público con el fin de "progresivamente diseñar un plan más concreto de seguros sociales de naturaleza pública ${ }^{76}$ en relación al inicio efectivo de sus competencias y sus

${ }^{68}$ Ibídem, pág. 116. Labor preparatoria de investigación y estudio, así como de documentación e información, que precede al ejercicio de la potestad legislativa o reglamentaria en la materia por los poderes públicos.

69 Ídem., Ministro de la Gobernación y político liberal, de la denominada Comisión de Reformas Sociales.

70 DE LA CALLE, VELASCO, M.D., «Sobre los orígenes del Estado Social en España», en DE LA VEGA. E., op. cit, pág. 136. "Canalejas, ministro de Agricultura, alcanza un pacto político, cuyo fin es poner en marcha un programa de reformas sociales. Convoca a varios profesores de Oviedo y les encarga el proyecto de un organismo administrativo con presupuesto y personal propios.»

${ }^{71}$ AZCÁRATE, G «Estudios sobre el problema social», en Estudios económicos y sociales, Madrid, 1876, págs. 125-126.

72 DE LA CALLE, VELASCO, M.D., op. cit., pág. 129.

${ }^{73}$ MONTERO, F., «De la Beneficencia a la reforma social. Los orígenes de la política social del Estado: estado de la cuestión, fuentes y archivos» en Rev. Espacio, Tiempo y Forma, Serie V, H. ${ }^{\text {a }}$ Contemporánea, t. 7, 1994. pág. 418.

${ }^{74}$ Ibídem., pág. 424.

75 DE LA CALLE, VELASCO, M.D, op. cit., pág. 146.

${ }^{76}$ GARCÍA MURCIA, J., CASTRO ARGÜELLES, M.A., La previsión social en España: del Instituto Nacional de Previsión al Instituto Nacional de Seguridad Social, M. ${ }^{\circ}$ de Trabajo e Inmigración, 2007, pág. 9. Buena muestra de ello fueron los Reales 
funciones ${ }^{77}$ para poner en marcha «operaciones de seguro con fines de cobertura de los riesgos sociales...a favor de personas de las clases trabajadoras ${ }^{78}$.

El Seguro de invalidez tuvo una iniciación práctica en el Reglamento general de 21 de enero de 1921 sobre el Retiro obrero obligatorio, siendo objeto de especial atención por el INP. Las conclusiones de la Conferencia Nacional de Seguros de enfermedad, invalidez y maternidad de noviembre de 1922 constituyeron el programa de trabajo para la organizar esas modalidades de previsión.

El de accidentes del trabajo se reguló en la Ley de 9 de septiembre de 1931, de gran importancia porque elevó a tal rango los Decretos dictados por la República en 9 de mayo, 12 de junio y 25 de agosto de 1931 para la aplicación de la Ley de Accidentes del trabajo en la agricultura. Sobre el Seguro de accidentes de los obreros de la industria se dictó la Ley de 4 de julio, siendo también antecedente de análoga reglamentación.

El Seguro de muerte tiene el precedente en el Real Decreto de 5 de marzo de 1910 que cristalizó en un proyecto de ley, de fecha 12 de junio de 1914, que sirvió de base al Decreto de 9 de diciembre de 1927, modificado por el de 22 de noviembre de 1929, creando este régimen, que fue regulado por el Real decreto de 24 de enero de $1930^{79}$.

Es de destacar la X Conferencia Internacional del Trabajo, celebrada del 25 mayo al 10 junio de 1927, que derivó en la aprobación de dos Convenios: uno relativo al Seguro de enfermedad de los asalariados de la industria y el comercio, de los trabajadores a domici-

Decretos de 29 de julio de 1917, que dispuso la celebración de una Conferencia Técnico-social para evaluar la oportunidad y las condiciones de implantación de los seguros sociales, y de 20 de noviembre de 1919, que, tras el balance de una década de funcionamiento de esa institución, aprobó ya un primer un plan de seguros a cargo de esa institución.

${ }^{77}$ Ibídem, pág. 22. El carácter pedagógico y cultural consistía en «difundir e inculcar la previsión popular», "administrar la mutualidad de asociados que al efecto y voluntariamente se constituya bajo este patronato, en las condiciones más benéficas para los mismos», naciendo aquí la clásica noción de entidad gestora, y la tercera tarea asignada al INP, era más política y "constructiva», en aras de "estimular y favorecer» las pensiones de retiro, "procurando su bonificación de carácter general o especial, por entidades oficiales o particulares».

${ }^{78}$ Ibídem, pág. 27.

${ }^{79}$ INSTITUTO NACIONAL DE PREVISIÓN, Unificación de los seguros sociales. Antecedentes de los seguros de enfermedad y de invalidez y muerte, Sobrinos de la Sucesora de M. Minuesa de los ríos, núm. 328, 1932, págs. 3-5. 
lio y de los domésticos, y otro referente a los asalariados de la agricultura.

Posteriormente ratificadas por las Cortes Constituyentes, las Leyes de 8 de abril de 1932, supusieron la implantación del Seguro de enfermedad en España. La importancia reside en que se tuvieron en cuenta las disposiciones internacionales como los trabajos de la XVI Conferencia Internacional del Trabajo con la colaboración de sectores sociales ${ }^{80}$ para el cumplimiento del fundamento jurídico del orden moral y para evitar afrentas entre el binomio asalariado-capital $^{81}$.

Un hecho clave que se escapa a muchos análisis de los orígenes del concepto jurídico de la vejez, muerte e invalidez de España, no reside tanto en la cantidad de legislación sobre la protección del trabajo sino el conglomerado administrativo que se creó para iniciar la legislación obrera, especialmente en los servicios de inspección y estadísticos que tanta falta hacían para favorecer la mejora del bienestar social de las clases obreras. Dicha labor novedosa de corte liberal krausista marcaría el inicio del desarrollo de la legislación sobre la protección social, aunque en aquel momento se ciñera a las relaciones de producción. A nuestro juicio, el aspecto más importante para el estudio del problema obrero en España fue la creación en 1894 del Servicio Especial de Estadística del Trabajo para atajar la «ausencia casi absoluta de estadísticas suficientes y fidedignas $»^{82}$.

Las Leyes de accidentes de trabajo (1900), mujeres y menores (1900) y descanso dominical (1904) constituyen, la base de la legislación obrera en España ${ }^{83}{ }^{84}$. Según STS de 17 de junio de 1903 entiende dos maneras de distinguir la invalidez: la primera como en-

${ }^{80}$ INSTITUTO NACIONAL DE PREVISIÓN, Apéndice XIII a la compilación del Instituto Nacional de Previsión, núm. 322, 1932, pág. 5.

${ }^{81}$ DERISI, O.N., Los Fundamentos Metafísicos del Orden Moral, prólogo de Tomás D. Casares, Buenos Aires, 1941, pág. 487, establece que « es innegable que a la observancia del orden moral establecido por la ley natural suelen seguirle como consecuencias intrínsecas la paz, la alegría, el aprecio, el amor de parte de los demás, la salud del cuerpo, etc., mientras que el remordimiento, el odio de los otros, ..., suelen ir aparejadas de sí, al quebrantamiento del orden moral.»

82 MAHVAUD, A, La cuestión social en España, Madrid, 1975, pág. 120.

83 PALOMEQUE LOPEZ, M.C., op. cit., págs. 99-117.

${ }^{84}$ POSADA, A. "La reforme sociale en Espagne», en Revue lntemationale de Sociologie, núm. 6, 1907, págs. 362-363. El problema de las normas anteriores, tenían una "categoría de buenas intenciones sin efecto positivo sobre la reglamentación efectiva de las relaciones de trabajo». 
fermedad contraída en el ejercicio de una profesión determinada, ${ }^{85}$ de otra sobrevenida ${ }^{86}$.

En derecho comparado de la época son significativos a este respecto la legislación suiza, alemana, francesa e italiana. La legislación suiza - más novedosa-trataba la enfermedad profesional estableciendo la responsabilidad del patrono en función de la tipología de su industria ${ }^{87}$. La legislación alemana no confundía el accidente de trabajo con la enfermedad profesional al someter a ésta última a un régimen de seguro obligatorio de enfermedad a nivel general. En Inglaterra en 1897, por orden médica, se delimitaba la declaración de enfermedad profesional causada por plomo, fósforo, arsénico, mercurio y el carbón cuando hubieran sido contraídas en una fábrica. En Francia, tras comisión extraparlamentaria en 1901, se redactaría la lista de enfermedades profesionales cuya causa orgánica estuviera relacionada con el ejercicio de la profesión y también la lista de profesiones con coeficiente de riesgo de invalidez o de muerte de dichas enfermedades. En Italia, por decreto de 19 de diciembre de 1901, se nombró una comisión de médicos para el estudio de la enfermedad profesional en la industria en la que se reconocía la dificultad de demostrar cuándo una enfermedad era contraída en el trabajo y por causa del trabajo aunque se afirmaba que "hay industrias en las cuales la relación entre las substancias empleadas y el modo de emplearlas y la enfermedad del obrero es clara, considerándose riesgo profesional ${ }^{88}$.

Tras asumir por España el apartado XIII del Tratado de Versalles de 28 de junio de 1919 relativo a la Organización del Trabajo, mediante la protección al trabajador contra las enfermedades generales o profesionales, las pensiones de vejez y de invalidez ${ }^{89}$ "para el es-

85 INSTITUTO DE REFORMAS SOCIALES, Preparación de la reforma de la Ley de accidentes de trabajo de 30 de enero de 1900. Informe de la Sección técnico-administrativa, Imprenta de la sucesora de M. Minuesa de los Ríos, Madrid, 1905, pág. 7 y 140 [recuperado el 13/01/2018, en https://expinterweb.empleo.gob.es/jspui/bitstr eam/123456789/479/1/1_069521_1.pdf]. Que no tiene «una relación absoluta e inmediata con aquella profesión, sino que depende del agotamiento o desgaste natural de las fuerzas empleadas en los trabajos que el individuo se dedique»

86 Ídem, De una manera directa e inmediata por consecuencia indudable del manejo de sustancias químicas o del ejercicio especial de un oficio o trabajo.

87 Ibídem, pág. 8. Las que engendran enfermedades graves el fabricante es responsable del daño causado al obrero por una de esas enfermedades graves cuando se demuestre que tiene como causa exclusiva la explotación de la fábrica»

88 Ibídem, pág. 11.

${ }^{89}$ INSTITUTO NACIONAL DE PREVISIÓN, Antecedentes de los seguros de enfermedad y de invalidez y muerte para la unificación de los seguros sociales, Imprenta de los sobrinos de la sucesora de M. Minuesa de los Ríos, 1932, núm. 328, pág. 3. Relativo al concepto: «cuando el fortalecimiento en las clases trabajadoras de su influencia política y económica se contraponga a la obra inmensa de reconstitución del capital.»

(C) UNED. Revista de Derecho UNED, núm. 23, 2018 
tablecimiento de la paz universal, y que tal paz solo pueda establecerse si se basa en la justicia social... que eviten disturbios tan grandes que la paz y la armonía del mundo suponga un peligro...y que garanticen la provisión de un salario digno $»^{90}$, el Real decreto de 20 de noviembre de 1919, supuso el plan de Seguros sociales comprendidos en la actuación del INP. Posteriormente, dos hechos importantes fijarían la evolución de los seguros en España: la Conferencia Internacional del Trabajo de 1932 y el proyecto de Inocencio Jiménez (1876-1941) en la unificación de los seguros sociales.

\section{A. La Conferencia Internacional del Trabajo de 1932}

No es hasta la XVI Conferencia internacional del trabajo en abril de 1932, donde Adolfo Posada (1860-1944) indica que faltaba la introducción de otros principios novedosos que, de implantarlos, requerirían cambios muy importantes y hasta convenientes de los seguros en España. En la discusión relativa a la obligatoriedad del seguro de retiro de vejez se plasma la inclusión en él de todos los asalariados, incluso los agrícolas, profesiones liberales y los trabajadores a domicilio excluyendo a los que ganasen un salario superior al determinado, los trabajadores demasiado jóvenes o de edad muy avanzada $^{91}$. Destaca que el cuestionario de la Oficina Internacional del Trabajo ${ }^{92}$ propusiera, en relación con el seguro de vejez, que variase la edad de retiro según las profesiones, es decir, que pudieran retirarse antes del límite de edad general, los obreros que trabajaren en profesiones insalubres. A este respecto, las orientaciones primarias del futuro convenio internacional obligarían, en caso de ratificar el convenio, a una transformación profunda en el régimen del retiro obligatorio en España. El espíritu reformista de los krausistas determinó un cambio drástico en los seguros sociales en aras de su eficacia y la economía. En cumplimiento de los artículos 46 y 65 de la Constitución de la República se reformaron los actuales Seguros so-

90 THE AVALON PROJECT, «The Versailles Treaty June 28, 1919: Part XIII» en Documents in Law, History and Diplomacy, Yale Law School, Lillian Goldman Law Library, 1919 [recuperado el 14/03/2018, en http://avalon.law.yale.edu/imt/partxiii. asp].

${ }_{91}$ Por decisión del consejo de administración de la Oficina internacional, no puede entrar en las deliberaciones de la XVI Conferencia.

92 INSTITUTO NACIONAL DE PREVISIÓN, "Conférence internationale du travail. Seiziéme session, 1932, L'Aaurancc invalité, viellesse et décés». Genéve, B.I.T., 1932, en Rev. Anales, núm. 95, 1932, págs. 68-73 [recuperado el 14/03/2018, en http://www.ingesa.msssi.gob.es/estadEstudios/documPublica/RevistasINP/pdf/ Anales_INP_95.pdf]. 
ciales de retiro obrero y de maternidad, y se implantaron los de invalidez, muerte y enfermedad. Un solo Seguro cubriría los riesgos de vejez, invalidez y muerte; otro, los de enfermedad y maternidad. La novedad residió en el tratamiento generalizador de inscripción obligatoria en estos Seguros a todos los asalariados, sin distinción de estado civil, sexo o nacionalidad, desde los 16 a los 65 años, acrecentándose con un subsidio por cargas de familia en función de si los recursos lo permitían, sin ser un derecho garantizado sino subversivo a la situación económica ${ }^{93}$.

El principio del seguro de invalidez residía en la prematura pérdida, con carácter permanente, de la capacidad del obrero para el trabajo ${ }^{94}$. Por lo tanto, determinando la deriva expuesta, se adoptó el criterio de no necesitar una especial inscripción del obrero contra el riesgo de invalidez en el que todos los mayores de dieciséis años y menores de sesenta y cinco años debían ser inscritos en los seguros unificados, quedando incluidos en el Seguro de invalidez, y a sus prestaciones, según la XVII Conferencia Internacional de Trabajo de Ginebra, en cuantía de «un tercio del salario habitual de un trabajador sano de una formación análoga $»^{95}$. En este punto es importante destacar la definición de inválido que se estimaba en la época por la que «será considerado como inválido, a los efectos de la Ley, todo el que, por causa no imputable a él ni derivada de un accidente de trabajo o enfermedad profesional indemnizable, no pueda ganar, en un trabajo adecuado a sus fuerzas, sus capacidades, su instrucción y la profesión ejercida anteriormente, un tercio, al menos, de lo que gane habitualmente un asalariado de la misma categoría, sano física y mentalmente, de instrucción análoga, en la misma localidad» ${ }^{96}$, quedando incorporada en las Bases aprobadas por el Pleno de la Comi-

${ }^{93}$ INSTITUTO NACIONAL DE PREVISIÓN, El proyecto de unificación de Seguros Sociales vistos en su conjunto, hojas divulgativas, núm. 19, Imprenta de los Sobrinos de Sucesora de M. Minuesa de los Ríos, 1935, pág. 479.

${ }^{94}$ INSTITUTO NACIONAL DE PREVISIÓN, Antecedentes de los seguros de enfermedad y de invalidez y muerte para la unificación de los seguros sociales, Imprenta de los Sobrinos de Sucesora de M. Minuesa de los Ríos, 1932, núm. 328, pág. 4.

95 INSTITUTO NACIONAL DE PREVISIÓN, El nuevo Seguro de invalidez en el Proyecto de unificación de seguros social, núm. 22, pág. 487, Imprenta de los Sobrinos de Sucesora de M. Minuesa de los Ríos, 1936, pág. 2. Recomendación relativa a los principios generales del Seguro de invalidez, vejez y muerte, adoptada en 29 de junio de 1933.

96 INSTITUTO NACIONAL DE PREVISIÓN, El nuevo Seguro de invalidez en el Proyecto de unificación de seguros sociales, Hoja divulgadora del Instituto Nacional

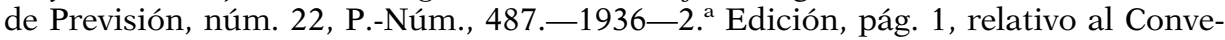
nio de 8 de junio de 1933, relativo al Seguro obligatorio de invalidez, aprobado en la XVII Conferencia Internacional del Trabajo, artículos 9 y 23. 
sión Asesora Nacional Patronal y Obrera el 13 de diciembre de 1934 para la reforma de los Seguros Sociales ${ }^{97}$, aprobándose en $1935^{98}$.

El proyecto de unificación de Seguros sociales no estaba basado «en la concepción simplista de llenar todos los fines de previsión con un solo seguro sino de agruparlos por yuxtaposición, es decir, manteniendo las diversas categorías de prestaciones, indemnizaciones y la clasificación de los seguros según las causas de las que resultase la pérdida de los medios de existencia, pero desde la coordinación ${ }^{99}$.

Es importante centrarse en las alternativas del sistema que se siguieron para adoptar un sistema de fusión o un sistema de coordinación. El primero, carecía de las estadísticas necesarias que hicieran efectiva la implantación de un seguro único para un único riesgo, la pérdida del salario. El sistema requería de una unidad legal, dentro de los seguros existentes, que permitieran mejores rendimientos y mayor eficacia que los que ya estaban en vigor. Posada ya avisaba sobre la experiencia en otros países con leyes «divergentes y contradictorias como generadoras de inconvenientes de todo orden en el que es precisamente en los países en que los Seguros Sociales se han desarrollado más intensamente, en donde se han sentido los inconvenientes de la falta de un plan general y en los que sería más racional buscar la realización de un sistema unitario del seguro social» ${ }^{100}$. Además, el seguro integral se enfrentaba con el principio de obligatoriedad, aceptado por los países de la Organización Internacional del Trabajo y también en España: «El seguro social ha de ser obligatorio y si en los seguros sociales subsisten zonas de voluntariedad, hay que considerarlas como concesiones a la transitoria necesidad de la preparación educativa de nuevas formas de seguro obligatorio»101 que terminó derivando en un sistema de unificación por coordinación.

97 INSTITUTO NACIONAL DE PREVISIÓN, XI Labor del Pleno (3-4 de diciembre de 1935). Resumen de las sesiones celebradas, acuerdos y documentación anexa, núm. 481, Imprenta de los Sobrinos de Sucesora de M. Minuesa de los Ríos, 1936, pág. 75. Las reformas se incorporaron al Proyecto de Ley para la Unificación de Seguros Sociales del año 1935.

98 Ibídem, págs. 84. En lo relativo al apartado III: Seguro de invalidez. El proyecto de unificación de los seguros sociales fue aprobado en el Texto aprobado por el Consejo de Patronato del Instituto Nacional de Previsión en 13 de septiembre de 1935.

99 JIMÉNEZ VICENTE, I, El Seguro Social y el Privado, Madrid, Instituto Nacional de Previsión, núm., 419, Imprenta de los Sobrinos de Sucesora de M. Minuesa de los Ríos, 1934, pág. 17.

100 BUREAU INTERNATIONAL DU TRAVAIL, Les problémes généraux de I'Assurance sociale, Ginebra, 1925, pág. 128.

101 JIMÉNEZ VICENTE, I, «El Seguro Social....», cit., pág. 9. 


\section{B. El proyecto de Inocencio Jiménez en la unificación de los seguros sociales en la XVII Conferencia Internacional del Trabajo de 1933}

El proyecto de unificación de los seguros sociales se plantea en España en los inicios de la II República para cumplir con los convenios internacionales suscritos por España. Es importante resaltar la vocación primitiva del INP en su propósito unificador ${ }^{102}$, en el que los trabajos realizados por el instituto debían ser coordinados con el de accidentes y régimen de retiro obrero porque formaban «un conjunto armónico e inseparable» ${ }^{103}$ debiendo organizarse con «un criterio de unidad que permitiese relacionarlos y coordinarlos de modo que constituyese un todo sistemático y armónico» ${ }^{104}$. Este modelo teórico, plasmado el abril de 1932, fue el que ratificó el Convenio de 1927 sobre los seguros de enfermedad derivando en la Orden Ministerial de 10 de Mayo de 1932 encarnando un proyecto de seguro social integrador que - muy importante- conseguía superar la resistencia patronal y al incluir a un mayor número de beneficiarios en función de la nueva organización que eliminaba antiguas discriminaciones de tipo sociolaboral, especialmente en el ámbito de la enfermedad tal y como especificaba lo manifestado en la XVII Conferencia Internacional del Trabajo de Ginebra de $1933^{105}$. No obstante, como ya hemos referido en otras ocasiones, las graves dificultades para que el Estado pudiese ejercer una política social efectiva recaían en «la ausencia de estadísticas de distribución de edades y salarios de las profesiones y el desempleo por falta de trabajo o enfermedad» ${ }^{106}$.

102 JIMÉNEZ VICENTE, I, La Unificación de los Seguros Sociales, Madrid, INP, núm. 45, Imprenta de los Sobrinos de Sucesora de M. Minuesa de los Ríos, 1936, pág. 3.

${ }_{103}$ DOMENECH, F., Organización administrativa del Seguro de enfermedad, maternidad e invalidez, tema 7, 1922, pág. 100 [recuperado el 4/12/2017, en http://bvingesa.mspsi.es/bvingesa/es/catalogo_imagenes/grupo.cmd?posicion=102\& config_usarPlugin $=\mathrm{N} \&$ path $=1000191 \&$ forma $=\&$ presentacion=pagina $\&$ responsabili dad_civil=on].

${ }_{104}$ Ibídem., pág. 108 [recuperado el 4/12/2017, en http://bvingesa.mspsi.es/ bvingesa/es/catalogo_imagenes/grupo.cmd?posicion $=110 \&$ config_usarPlugin= N\&path=1000191\&forma=\&presentacion=pagina\&responsabilidad_civil=on].

105 RUIZ MANENT, J.M, Los seguros sociales de invalidez, vejez y muerte ante la XVII Conferencia Internacional del Trabajo, núm. 391, Imprenta de los Sobrinos de Sucesora de M. Minuesa de los Ríos, 1933, pág. 5.

106 INSTITUTO NACIONAL DE PREVISIÓN. Situación de los estudios para el seguro de vejez, invalidez y muerte, núm. 407, 1934, pág. 35 [recuperado el 4/12/2017, de http://bvingesa.msc.es/bvingesa/es/catalogo_imagenes/grupo.cmd?path=1001964]. 
El proceso más transcendental para Inocencio Jiménez consistió en aprovechar la experiencia ${ }^{107}$ de los países de la Conferencia para buscar una racionalización del sistema de seguro social más unitario $^{108}$ con un mismo fin genérico: «acudir en auxilio de los económicamente débiles en las necesidades anormales, pero generalizadas, que no pueden ser atendidas con los ingresos normales, de una manera coordinada con el Seguro de Enfermedad y relacionada con el Seguro de Accidentes mediante una sola institución que asegurase prestaciones diferentes a los diferentes riesgos y necesidades, hecho que favorecía la economía del seguro social y la economía nacional» ${ }^{109}$, desde un principio finalista que procurase la «remediar la pérdida total o parcial de la capacidad laboral, compensada por retribución o devolviendo la capacidad perdida por motivos de salud» ${ }^{110}$.

La ponencia designada en 1932 de la que surgieron varias subponencias fue la que estableció las bases para los nuevos seguros en el proceso unificador partiendo de una base legal ${ }^{111}$ que condensase los seguros sociales en un sistema por coordinación mediante «reglas de base». Las relativas al concepto de invalidez fueron las siguientes:

- Base primera: Reforma de los Seguros sociales bajo un régimen de unificación, destacando la conversión del Régimen legal de Retiro Obrero obligatorio en el Seguro de Vejez, Invalidez y Muerte, conforme a los Convenios votados en la Conferencia Internacional del Trabajo de 1933 y la implantación del Seguro de Enfermedad para cumplir con la Ley de Bases de la Unificación de los Seguros sociales con los principios de la Ley de 27 de febrero de 1908.

107 JIMÉNEZ, I., La Unificación de los Seguros Sociales, INP, núm. 440 Imprenta de los Sobrinos de Sucesora de M. Minuesa de los Ríos Madrid, 1934, pág. 5 [recuperado el 07/12/2017, de http://bvingesa.msc.es/bvingesa/es/catalogo_imagenes/ grupo.cmd?path=1001626\&responsabilidad_civil=on\&aceptar=Aceptar].

108 Ibídem., pág. 6. Así, dicha experiencia se fue fraguando en la Conferencia de 1925 para el Seguro de Accidentes, y la Conferencia de 1933 para los Seguros de Invalidez, Vejez y Muerte. Para la racionalización del seguro en España sirvió la experiencia del Estudio de los problemas generales de los Seguros Sociales en la respuesta que los países miembros tuvieron respecto de la disyuntiva coordinación o unificación. Cfr. ORGANIZATION INTERNATIONALE DU TRAVAIL, "Sécurité du revenu et protection sociale dans un monde en mutation» en Rapport sur le travail dans le monde 2000, Bureau International du travail de Genève, Genéve, 2000, pág. 1.

109 Ibídem, págs. 9-27.

110 Ibídem, pág. 28.

111 Ibídem, pág. 31. Primero, la ampliación del Seguro de Maternidad; segundo, el Seguro de Vejez, Invalidez y Muerte, y tercero, el Seguro de Enfermedad. 
- Base tercera: La afectación del salario en el concepto de la invalidez incluía todo lo que se considerase salario según lo recogido en la Ley de Contrato de trabajo de $1931^{112}$ que, según su art. 27, se consideraba "a la totalidad de los beneficios que obtuviera el trabajador por sus servicios u obras» ${ }^{113}$.

- Base cuarta: El concepto jurídico de inválido se definía como el asegurado que por causa no imputable a él, ni derivada de un accidente del trabajo, tuviera reducida su capacidad de trabajo en forma tal que no le fuese posible tener un salario superior al tercio del que, con la misma formación y en el mismo lugar, pudiera obtener un trabajador en condiciones normales de salud. El objetivo del concepto jurídico de invalidez se trasladaba a la readaptación que pudiera evitar las consecuencias de su invalidez $z^{114}$ ya sea mediante servicios y/o prestaciones en metálico, alcanzando también a su familia.

En cuanto a las conclusiones de las subponencias el avance más importante fue la definición de invalidez y asalariado, objeto de las Bases 2. ${ }^{\mathrm{a}}, 3$. $^{\mathrm{a}}$ y 10 , incluyéndose la 1. ${ }^{\mathrm{a}}$, por las que la Comisión determina una mayor precisión de la definición que la adoptada por los Convenios de Ginebra debido a que la calificación de apreciable, dada por el Convenio a la remuneración que obtenía con su trabajo el asegurado para que lograda no tuviera derecho a pensión de invalidez, se prestaba a interpretaciones de carácter subjetivo ${ }^{115}$.

112 MARTÍNEZ, V., HERRERO, J.B., Sistema de derecho del trabajo, publicaciones U.R.V., Tarragona, 2015, pág. 66. Ley de 21 de noviembre de 1931 sobre contrato de trabajo.

113 Ibídem, págs. 67. No sólo en metálico o en especie, sino también las indemnizaciones por espera, por impedimentos o interrupciones del trabajo, cotizaciones del patrono para los seguros y bienestar, beneficios a los herederos y conceptos semejantes.

114 JIMÉNEZ, I., «La Unificación...», cit., págs. 36-40.

115 INSTITUTO NACIONAL DE PREVISIÓN, Unificación de los seguros sociales. El seguro de vejez, invalidez y muerte. Labor de la subponencia y conclusiones, Imprenta de los Sobrinos de Sucesora de M. Minuesa de los Ríos, Madrid, 1934, pág.14. Mientras que los Convenios relativos al Seguro de invalidez consideran con derecho a pensión de invalidez al asegurado «cuando sufra una incapacidad general que le imposibilite para procurarse con su trabajo una remuneración apreciable» (artículo $4 .^{\circ}$, párrafo $1 .^{\circ}$ ), cosa bastante imprecisa, y aun exime al Seguro, en ciertos casos (art. $4 .^{\circ}$, párrafo $2^{\circ}$ ), se concede la pensión de invalidez a los asegurados capaces de realizar un trabajo asalariado, la Base 10 de la Comisión exige, para que el asegurado tenga derecho a invalidez, que encuentre «reducida su capacidad en forma tal que no le sea posible obtener un salario superior a un tercio del que con la misma formación y en el mismo lugar obtuviere un trabajador en condiciones normales de salud». 
Así, la ratificación de los acuerdos internacionales se inscribían en la línea emprendida por los gobiernos republicanos en materia social, dado que se establecía un nuevo rango legal a las pautas tradicionales en el INP en 1936, subscribiendo las recomendaciones internacionales en el marco del "principio de solidaridad humana al servicio de los más débiles por medio de una actuación internacional en Convenios» ${ }^{116}$, en la que se tuvo en cuenta la situación de los seguros sociales en Europa hasta $1932^{117}$.

Finalmente, la influencia del reformismo social krausista fue la que inició el movimiento de intervención del Estado en las relaciones de producción, contrariamente a movimientos radicales liberales y a propuestas revolucionarias socialistas y anarquistas. Este intervencionismo implantó «reformas legislativas prácticas, razonables y elevadas inspiradas en un sentimiento de profunda justicia buscando en ellas un medio de satisfacer las aspiraciones legítimas de los trabajadores y de afianzar la paz social $\aleph^{118}$ debido al cariz que estaba tomando la complejidad del problema social por razones económicas, de supervivencia del sistema, los movimientos obreros y por condicionantes ideológicos ${ }^{119}$.

Coincidimos con Alonso García en que dicha concepción ideológica, tenía en común, con otras concepciones sociológicas, «la reivindicación del trabajo como valor moral y como mecanismo de desarrollo de la persona, siendo inherente a la dignidad de ésta» ${ }^{120}$. En este sentido, coincidimos con Hilario Yaben en que el derecho natural «no sólo justificaba la adopción de normas preventivas con el fin de salvaguardar el derecho a la dignidad e integridad de todo trabajador, sino que requería también como consecuencia lógica de estas medidas, reglas reparadoras o indemnizatorias, para el supuesto de que ocurriera una contingencia en el marco de las relaciones productivas» ${ }^{121}$. Considerando esta afirmación en línea de los refor-

116 JIMÉNEZ, I., «La Unificación...», op. cit., pág.5.

117 SAMANIEGO-BONEU M. «Hacia la unificación de los seguros sociales: el intento integrador de la II República» en Rev. Studia Historica. Historia Contemporánea, 1984, vol. 2, págs. 119-121 [recuperado el 12/12/2017, en https:/gredos.usal.es/ jspui/bitstream/10366/79946/1/Hacia_la_unificacion_de_los_seguros_soci.pdf].

118 ESPUNY TOMAS, M.J., "Eduardo Dato y la legislación obrera» en Historia Social, núm., 43, 2002, pág. 14.

119 GARCÍA GONZÁLEZ, G., «Los inicios del reformismo social en España: la primera legislación social y la comisión de reformas social» en Revista Gaceta Laboral, Vol. 14, Núm. 2, 2008, págs. 251-270, pág. 253 para la cita.

120 Ibídem, pág. 254. Cfr. ALONSO GARCİA, M., Curso de Derecho del Trabajo, Boch, Barcelona, 1964.

121 Ídem., Cfr. YABEN YABEN, H., Exposición y crítica del llamado intervencionismo del Estado, Madrid, Establecimiento tipográfico de Jaime Ratés, 2014. 
mistas krausistas - en su interacción con el iusnaturalismo científico- este proceso consolidaba los derechos individuales y sociales dando importancia a los valores como resultado del proceso histórico y bajo una base cultural y social y sin que dicho proceso supusiese un rechazo de los principios éticos ${ }^{122}$. Por ello la influencia del krausismo en la norma fundamental de 1931 intentó el objetivo ético de consolidar un régimen democrático legitimado por los derechos individuales y sociales que, mediante un nuevo iusnaturalismo, entendía los valores «como resultado del proceso histórico y como cristalizaciones culturales y sociales sin incurrir en el famoso «dualismo de esferas» ${ }^{123}$.

Por lo tanto, el krausismo y las posibilidades del giro científico que comportó el nuevo discurso jurídico-político, tanto en el nivel de la práctica institucional, como en el plano intelectual, produjo una incorporación selectiva de los retos señalados por aquel, para la ciencia política, «el arsenal de elementos, los principios de la técnica y la nomenclatura que forman una base propicia para trabajar con fruto» ${ }^{124}$. Lamentablemente, hoy en día comportaría una gran dificultad, en virtud de una orientación hacia un perfil organicista-economicista que promulga la ruptura de la Constitución material del Estado Social, en la que rige «la constitucionalización de la estabilidad presupuestaria como premisa material incuestionable» ${ }^{125}$.

La diferencia de la mentalidad krausista con la ideología actual reside, aunque ambas europeizadas, en que la actual responde únicamente a una coyuntura intervencionista de carácter exclusivamente económica mientras que la krausista «respondía a las exigencias históricas que planteaba la democracia social y constitucional» $^{126}$.

122 MARTÍN MARTÍN, S., «Funciones del jurista y transformaciones del pensamiento jurídico-político español (1870-1945)», vol. II, en Revista Electrónica de Historia Constitucional, núm. 12, 2011, pág. 162 ss.

123 Ibídem., pág. 164. Se trataba de un iusnaturalismo desde el historicismo pero con una base cultural y social alejada del «derecho natural escolástico sin incurrir en el peligro hegeliano y prefascista de considerar que todo lo real era racional, pues siempre cabía interponer frente a lo instituido unos valores racionales extraídos de la misma realidad cultural, parcialmente cristalizados en las normas, pero nunca satisfechos por completo, debido precisamente al carácter irrestañable del proceso histórico.»

${ }^{124}$ MARTÍN MARTÍN, S. op. cit., pág. 117.

125 LASA LÓPEZ, A., "La ruptura de la Constitución material del Estado Social: La Constitucionalización de la estabilidad presupuestaria como paradigma», en RUNED. Revista de Derecho Político, núm. 90, Mayo-Agosto, 2014, págs. 214-247, pág. 219 para la cita [recuperado el 15/02/2018, en http://revistas.uned.es/index.php/ derechopolitico/article/view/13161].

126 MARTÍN MARTÍN, S., op. cit., pág. 165. 


\section{EL CONCEPTO JURÍDICO DE INVALIDEZ EN RELACIÓN CON EL CONCEPTO DE DIGNIDAD HUMANA}

El concepto jurídico de dignidad en relación con los derechos humanos, aparece en la Carta de Derecho Humanos de 1945, la Declaración Universal de Derechos Humanos de 1948 en su artículo 25127, el Pacto Internacional de Derechos Civiles y Políticos de 1966, el Pacto Internacional de Derechos Económicos, Sociales y Culturales de 1966 y en todas las constituciones después de la Segunda Guerra Mundial, las cuales, estipularon los principios de justicia, lo cual implicó un cambio importante en la transformación de los Estados constitucionales respecto a las anteriores concepciones. La dignidad en el constitucionalismo europeo, se encuentra recogido en las Constituciones de Irlanda (1937), Italia (1947), Alemania (1949), Portugal (1976) y España (1978), aunque la elevación de la dignidad de la persona a la categoría de núcleo axiológico constitucional como derecho fundamental no ha llegado a una definición satisfactoria en todas ellas, como ocurre con la española.

Como prueba de ello, el Tribunal Constitucional español ha señalado que la relevancia y la significación superior del valor de la dignidad se manifiestan en el artículo 10 de la Constitución de 1978, siendo considerada como el punto de arranque, para la existencia y especificación de los demás derechos. No obstante, la dignidad de la persona no opera en el ordenamiento español como un derecho fundamental ${ }^{128}$. Su ubicación constitucional significa que la intención del constituyente fue considerarla como fuente de los derechos que le son inherentes, en lugar de un derecho fundamental. Por consiguiente, la dignidad no puede ser considerada como un derecho fundamental, en la medida que al no ubicarse dentro del Capítulo II de la Constitución española, no goza de la tutela preferente establecida por el artículo 53.2. ${ }^{\circ 29}$, con lo que, es ajena a los derechos funda-

127 Declaración Universal de Derechos Humanos de 1948 [recuperado el 26/12/2017, en http://dudh.es/tag/dignidad-humana/]. «Toda persona tiene derecho a un nivel de vida adecuado que le asegure, así como a su familia, la salud y el bienestar, y en especial la alimentación, el vestido, la vivienda, la asistencia médica y los servicios sociales necesarios; tiene asimismo derecho a los seguros en caso de desempleo, enfermedad, invalidez, viudez, vejez u otros casos de pérdida de sus medios de subsistencia por circunstancias independientes de su voluntad».

${ }_{128}$ Tribunal Constitucional español. STC 337/1994 en MURILLO, J.M., La naturaleza jurídica de la dignidad humana: un análisis comparado de la jurisprudencia del Tribunal Constitucional Español y el Tribunal Constitucional Federal Alemán, Tesis de Grado, 2012, pág. 122

129 Constitución española de 1978. Artículo 53.2. : "Cualquier ciudadano podrá recabar la tutela de las libertades y derechos reconocidos en el artículo $14 .^{\circ}$ y la Sección 1. ${ }^{\mathrm{a}}$ del Capítulo II ante los Tribunales ordinarios por un procedimiento basado 
mentales susceptibles de protección a través de este proceso constitucional (los derechos reconocidos en los artículos 14 a $29 \mathrm{CE}$ ) ${ }^{130}$ rechazándose con ello que la dignidad, per se, pueda ser considerada como un derecho fundamental ${ }^{131}$.

A este respecto, en la afirmación de Posada «derechos de personalidad» quedaría recogida la dignidad entendida en la dimensión social como derechos subjetivos atribuyendo a cualquier persona una personalidad jurídica - según la fórmula de Hannah Arendtcomo «el derecho a tener derechos» a fin de reivindicación frente al Estado. De ahí, que el constituyente desligase la definición de los derechos fundamentales de la Constitución de 1978 tanto de la caracterización de la construcción civilista como de la de los derechos subjetivos de los años 20 y 30, con consecuencias decisivas hasta hoy día ${ }^{132}$.

Al contrario, en la Constitución italiana de 1948 se encuentra reconocido en el Título Constitucional dedicado a los «Principios Fundamentales» en el artículo 2, que reconoce la fórmula de los «derechos inviolables de la persona ${ }^{133}$ por lo que «la dignidad se presenta como un plus-valor, en tanto es el centro del principio personalista, que junto al principio de igualdad, sustentan el gran edificio del constitucionalismo contemporáneo ${ }^{134}$.

En la Constitución alemana, el artículo 1. ${ }^{\circ} 16$ de la Ley Fundamental, a diferencia de los otros artículos relativos a derechos fundamentales, es inalterable de cualquier modificación constitucional, de acuerdo con el artículo $79.3^{\circ}$ de la Ley Fundamental. Así, está por encima de cualquier reforma ${ }^{135}$, es decir, es considerada «un bien en sí mismo, independiente de las condiciones personales y so-

en los principios de preferencia y sumariedad y, en su caso, del recurso de amparo ante el Tribunal Constitucional.

130 Tribunal Constitucional. STC 53/2004 en MURILLO, J.M. op. cit., pág. 125 No puede servir de base a una pretensión autónoma de amparo, por impedirlo los artículos 53.2. ${ }^{\circ}$ y 161.1.b. ${ }^{\circ}$ de la Constitución y el artículo $41.1 .^{\circ}$ de la Ley Orgánica del Tribunal Constitucional.

131 Tribunal Constitucional. STC 53/1985 en MURILLO, J.M. op. cit., pág. 124

132 GARCÍA MARTÍN, J., op. cit., pp. 170-174.

133 BONILLA, M., "La dignidad humana en la jurisprudencia de la Corte Constitucional Italiana» en, Revista de Ciencias Jurídicas, Universidad de Costa Rica, núm. 119, 2009, pág. 41, recuperado el 15/12/2017, en https://revistas.ucr.ac.cr/ index.php/juridicas/article/download/9774/9220. En su artículo 3 determina que «Todos los ciudadanos tendrán la misma dignidad social y serán iguales ante la ley, sin distinción de sexo, raza, lengua, religión, opiniones políticas, ni circunstancias personales y sociales.»

134 Ibídem, pág. 42.

135 MURILLO, J.M., op. cit., pág. 126. 
ciales, de las cualidades y de los defectos del sujeto, de modo que a cada uno le sea reconocido el derecho a que su individualidad sea preservada ${ }^{136}$.

Por todo ello, podemos deducir que el concepto jurídico de invalidez presenta un principio personalista en forma de preservación de su individualidad. No obstante, alejado del concepto de dignidad en España, ninguno de los dos han gozado de los privilegios del derecho fundamental por no ser considerados como tal. Por lo que se necesita realizar otro salto histórico como efectuaron los reformistas cuando equipararon el derecho social de la invalidez con el estatus derecho legal aunque sólo hacia los trabajadores asalariados ${ }^{137}$.

\section{CONCLUSIONES}

La unificación de los seguros sociales en el espíritu de la Constitución de 1931, consistía de dar cumplimiento a los convenios internacionales y sobre todo a lo que el proyecto significaba en «la satisfacción de una aspiración unánime de la clase trabajadora, en la máxima medida que las circunstancias lo hagan posible... para el desarrollo de los humanitarios preceptos contenidos en los artículos 46 y 65 de la Constitución de la República» constituyendo, «... una obra de justicia y de paz social» ${ }^{138}$.

En relación a la comparación del concepto jurídico de invalidez con la condición de inválido se sistematiza la asistencia a los inhábiles, más bien enfocado a prevenir revueltas sociales con el objetivo de mantener el orden público y combatir el pauperismo que no como un derecho exigible, distinto a lo que se producirá con la unificación de los seguros sociales.

El momento histórico más destacable corresponde con la XVII Conferencia Internacional de Trabajo de Ginebra y las ideas del reformismo krausista por las que se empieza a definir, por ley, el concepto jurídico de la invalidez relacionado con el trabajo, atendiendo al principio de solidaridad humana al servicio de los más

136 BONILLA, M., op. cit., pág. 45.

137 ARANGO RIVADENEIRA, R., «Derechos Sociales» en Enciclopedia de Filosofía y Teoría del Derecho, Vol. II, pág. 1678 [recuperado el 14/01/2018, en https:// biblio.juridicas.unam.mx/bjv/detalle-libro/3796-enciclopedia-de-filosofia-y-teoriadel-derecho-volumen-dos].

138 INSTITUTO NACIONAL DE PREVISIÓN, "El proyecto de unificación de los seguros sociales vistos en su conjunto", Madrid, n. ${ }^{\circ}$ 479, Hoja divulgadora, núm. 19, 1935., pág. 1. 
débiles desde la exigibilidad del derecho y no como una acción benéfica. El salto cualitativo de los reformistas puede entenderse, en relación con los derechos sociales, como la respuesta por medio de intervenciones legislativas frente al desafío que el constitucionalismo liberal vedaba de forma radical. No obstante, no consiguieron que esos derechos adquirieran el estatus de derechos subjetivos sino que, sobre la base de un estado garantista y democrático atenuado, derivaba en una falta de reconocimiento generalizado ${ }^{139}$ del concepto de invalidez a todas las personas pero exclusivamente reducido al ámbito del trabajo, mediante la tendencia a presentar una universalización abstracta del concepto, ignorando al inválido que no trabaja, cuya construcción se ha proyectado hasta nuestros días ${ }^{140}$.

Heredado de la Europa continental de finales del siglo XIX, España consolidó también a la administración como responsable de las nuevas competencias públicas que fueron surgiendo a raíz de la industrialización y de la cuestión social en las que no sólo vino a definirse como legicéntrico, sino también como administrativo. Legicéntrico en tanto los derechos no preexisten a las leyes sino que son resultado de las mismas, porque en ellas está su realización y garantía, y en cuanto se cancela un modelo anterior de justicia y se excluye de la función judicial cualquier posibilidad de creación del derecho; administrativo porque se deposita en la administración el monopolio de las competencias públicas y se le dota de instrumentos jurídicos para su realización ${ }^{141}$ y reconocimiento o cancelación del derecho a la discreción económica del país como ocurre en nuestros días.

En relación a la metafísica del concepto jurídico de invalidez ${ }^{142}$ coincidimos con Espinosa en que bajo la lógica hegeliana se condiciona, por esta definición, el resto de los derechos. La lógica de la definición, intenta ser unívoca y universal en lo que respecta a la variedad de la cosa, el concepto de invalidez, aunque sin serlo, con lo que la propia definición no adapta la lógica a aquella, que por otra parte sí hace Aristóteles. En este sentido, a la definición de inválido se le aplica la misma lógica a cualquier profesión por lo que sería criticable por su alejamiento de la realidad en relación a la aplica-

139 PISARELLO, G., op. cit., págs. 29-30.

140 Ibídem., pág. 31.

141 LORENTE, M. y PORTILLO, J.M., op. cit., págs. 373-374.

142 ESPINOSA ARES, J.M., "Tras la Subjetividad Jurídico-Política Moderna» en $2{ }^{\circ}$ Curso del Seminario Permanente Poder, Libertad, Ley Departamento de Filosofía Jurídica, UNED, 2017, [recuperado el 17/11/2017, en https://canal.uned.es/serial/ index/id/6040]. 
ción de la definición a la totalidad de la cosa. Esta definición también sería criticable desde el punto de vista kantiano porque se entiende que es el Estado el único defensor y garante de lo individual en la que el individuo no está al mismo nivel. El conflicto entre la definición de la cosa, o el concepto de invalidez de la época, presenta deficiencias debido a la mejorable definición de la cosa y las circunstancias individuales de los individuos, con lo que no se cumple la teoría de que ambos, Estado e individuo, son libertad. Prueba de ello es la coletilla final de la definición del concepto de invalidez que hace referencia a la misma localidad que condiciona toda la definición por la que se da a entender que computando todos los requisitos para el reconocimiento de la condición de invalidez, la determinación de ésta, va a depender de la zona del territorio donde se produzca el hecho causante.

En lo relativo al concepto jurídico de dignidad en el concepto de invalidez, tras los logros de los reformistas, la significación del concepto jurídico de invalidez cambió por serle concedido el carácter de derecho, exclusivamente desde el ámbito del trabajo, siendo su objeto, anteriormente a ellos, una mera aspiración. Tras los grandes avances de los reformistas, hubiera sido el momento para que el derecho a la dignidad humana y, por ende, el reconocimiento del derecho social del concepto de invalidez fuera reconocido como fundamental con carácter de derecho subjetivo, el cual podría haber sido objeto de prestaciones positivas fácticas del Estado ${ }^{143}$ por considerarse la invalidez como derecho fundamental, hecho que habría llegado hasta nuestros días. Su fundamentación en la dignidad como principio resultaría decisiva para garantizar su autonomía en el ejercicio los derechos fundamentales ${ }^{144}$. Coincidimos con Lasarte en que, a partir del texto gaditano, la idea de Nación económica se superpuso a los derechos individuales ${ }^{145}$.

No obstante, el impulso reformista en la mejora de la protección a la invalidez mediante una serie de derechos de prestación exigibles, supuso una rebelión contra la imposición de condiciones opresivas o humillantes de vida. Si entendemos que la justificación del derecho de prestación en la invalidez sustenta la remoción del daño, la idea de dignidad o de una vida digna queda vinculada al conjunto de condiciones que permiten preservar la integridad física y psíquica con el fin de minimizar, por aquel derecho de prestación, la autonomía y el libre desarrollo de la personalidad. Esto se justifica me-

143 ARANGO RIVADENEIRA, R., op. cit., pág. 1677.

144 GARCÍA MARTÍN, J., op. cit., pág. 202.

145 Véase cita 42. 
diante la satisfacción de las necesidades que permitieron al inválido empezar a perseguir libremente fines y planes de vida propios y participar en la construcción de la vida social ${ }^{146}$. Por ello, los derechos de prestación relacionados con la invalidez en la reforma de los seguros sociales, al garantizar unas mínimas condiciones para una vida digna, fueron el inicio de la garantía del libre desarrollo de la personalidad de cada ciudadano en la sociedad ${ }^{147} \mathrm{y}$, por ende, el inicio del desarrollo del principio de dignidad al transformar del concepto de inválido, no como un derecho encasillado al ámbito militar sino como derecho exigible. No obstante, no se impidió la subversión liberal-capitalista consistente en degradar el concepto de dignidad relevante del hombre y del sentido de la vida, por la consideración de aquel como objeto-exclusivamente-de mercado ${ }^{148}$. Finalmente, se hubiera deseado un iusnaturalismo ya propulsado por la Declaración Universal por los Derecho del Hombre, en la que se hubiera incidido en la dignidad innata y en los derechos iguales e imprescriptibles de los seres humanos. Siendo innata, no originada por el tenor de la legislación positiva. Siendo imprescriptibles tales derechos, no dependientes de la costumbre ${ }^{149}$.

146 PISARELLO, G., op. cit., pág. 39.

147 RODRÍGUEZ ARANA, J., "Los derechos fundamentales sociales» en Derecho administrativo $y$ derechos sociales fundamentales, Instituto Nacional de Administración Pública, 2015, págs. 363-583, págs. 363-364 para la cita [recuperado el 15/03/2018, en https://app-vlex-com.ezproxy.uned.es/?r=true\#/vid/594842858/ download].

148 FERNÁNDEZ GARCÍA, E., "Sobre la pertinencia y tensiones de la autonomía, la libertad y la igualdad como fundamentos de los derechos económicos y sociales», en Valores constitucionales y derecho, Dykinson, Madrid, págs. 49-78, pág. 73 para la cita. [recuperado el 14/03/2018, en https://app-vlex-com.ezproxy. uned.es/?r=true\#/vid/192339949/download].

149 PEÑA, L. «La fundamentación jurídico-filosófica de los derechos de bienestar» en Los derechos positivos. Las demandas justas de acciones y prestaciones, Ed. Plaza y Valdés, 2006, pág. 205 [recuperado el 14/03/2018, en http://vlex.com/vid/ fundamentacion-filosofica-bienestar-65947040]. 
